\title{
REVIEW
}

\section{FSH-metabolic circuitry and menopause}

\author{
Charit Taneja, Sakshi Gera, Se-Min Kim, Jameel Iqbal, Tony Yuen and Mone Zaidi \\ The Mount Sinai Bone Program, Department of Medicine, Icahn School of Medicine at Mount Sinai, New York, New York, USA \\ Correspondence should be addressed to C Taneja: charit.taneja@mountsinai.org
}

\begin{abstract}
FSH has a primary function in procreation, wherein it induces estrogen production in Key Words females and regulates spermatogenesis in males. However, in line with our discoveries over the past decade of non-unitary functions of pituitary hormones, we and others have described hitherto uncharacterized functions of FSH. Through high-affinity receptors, some of which are variants of the ovarian FSH receptor (FSHR), FSH regulates bone mass, adipose tissue function, energy metabolism, and cholesterol production in both sexes. These newly described actions of FSH may indeed be relevant to the pathogenesis of bone loss, dysregulated energy homeostasis, and disordered lipid metabolism that accompany the menopause in females and aging in both genders. We are therefore excited about the possibility of modulating circulating FSH levels toward a therapeutic benefit for a host of age-associated diseases, including osteoporosis, obesity and dyslipidemia, among other future possibilities.

\section{Introduction}

The early menopausal transition is associated with a sharp rise in serum FSH levels, even when serum estrogen levels remain within normal limits (Randolph et al. 2003). The median age of menopause in the United States is 51.4 years, while the average age for the start of the perimenopausal transition is 47 years, as defined by The Stages of Reproductive Aging Workshop (STRAW) (Harlow et al. 2012). This transition is marked by changes in bone remodeling, body composition, and energy metabolism, all of which are most prominent during the late perimenopause (Perrone et al. 1995, Ebeling et al. 1996, Ito et al. 1999, Chapurlat et al. 2000, Recker et al. 2000, Seifert-Klauss et al. 2002, 2006). The Study of Women's Health Across the Nation (SWAN) studied a large cohort of perimenopausal women (42-52 years of age) and examined biological parameters, including bone mass and body fat, among others, in relation to endogenous hormone levels at various stages of the perimenopause and post-menopause (Sowers et al. 2003, 2006). The study, performed longitudinally for over a decade, revealed a decline in bone mineral density (BMD), together with increased body weight, visceral adiposity, disrupted energy homeostasis and reduced physical activity (Thurston et al. 2009, Senapati et al. 2014). The occurrence of these metabolic aberrations in the face of rising serum FSH levels with relatively unchanged serum estrogen prompted our consideration of alternate mechanism(s) of menopausal bone loss and obesity rather than the generally accepted unitary attribution to estrogen deficiency.

We published the first evidence for a role of FSH in the regulation of bone mass in mice (Sun et al. 2006). FSH increased bone resorption by enhancing the genesis and function of osteoclasts and increasing survival (Sun et al. 2006, 2010). More recent studies have shown that FSH is a primary regulator of body fat and energy homeostasis (Liu et al. 2015, 2017). Notably, we found increases in bone mass and lowered body fat in mice treated with an antiFSH antibody, as well as in mice genetically deficient in 
FSH or the FSHR (Sun et al. 2006, Liu et al. 2017, Rosen \& Zaidi 2017, Ji et al. 2018). A further interesting observation was the induction of thermogenic 'beige' adipose tissue and, as a consequence, increased energy expenditure in antibody-treated mice (Liu et al. 2017). Extending our premise for the existence of novel pituitary-metabolic circuits of physiological and medical significance (Zaidi 2007, Zaidi et al. 2018a,b), the link between serum FSH, osteoporosis and obesity lays a firm foundation for using a single FSH-blocking agent to prevent and/or treat both postmenopausal osteoporosis and obesity.

\section{Clinical association between FSH and bone loss}

The SWAN study reported that the rate of bone loss is highest during the perimenopause period despite normal estrogen levels. The mean annual decrement in lumbar spine BMD was highest between 1 year prior to and 2 years after the last menstrual period, although the BMD values remained within normal range at this time (Sowers et al. 2003, 2006, Crandall et al. 2013). This bone loss during the menopausal transition has been confirmed by increased bone turnover markers, including N-terminal telopeptide (NTX) (Seifert-Klauss et al. 2002). A bone biopsy cohort showed evidence of increased osteoclastic resorption, noted as accelerated activation frequency as early as one year after menopause (Recker et al. 2004). Bone loss was found mainly to occur in trabecular bone, characterized histologically by decreases in trabecular number and increased trabecular perforations. Marked changes in trabecular bone structure, noted on micro-CT $(\mu-\mathrm{CT})$ and histomorphometry, included decreased bone volume density and trabecular number, and increased trabecular spacing (Akhter et al. 2007).

A number of correlative studies have also confirmed a relationship between rising serum FSH levels and bone loss, independently of serum estrogen (Adami et al. 2008, Xu et al. 2009, Gallagher et al. 2010, Wu et al. 2010, GarciaMartin et al. 2012, Crandall et al. 2013). Notably, the Italian Bone Turnover Range of Normality (BONTURNO) study and a study from Spain both showed a positive correlation between high serum FSH and bone turnover markers, including osteocalcin and C-terminal telopeptide of type 1 collagen (CTX), irrespective of estradiol levels (Adami et al. 2008, Garcia-Martin et al. 2012). Likewise, a study investigating the relationship between urinary cadmium, serum FSH and femoral BMD in a cohort of women from US NHANES III (aged 42-60 years) showed an independent inverse association between FSH and
BMD in certain groups (Gallagher et al. 2010). Similarly, Cannon and coworkers reported an inverse relation between FSH and BMD, independent of variables, such as serum estradiol, LH and inhibin B in 36 women between the ages of 20 and 50 years (Cannon et al. 2010). Multiple studies from China have also reported strong correlations between high serum FSH and bone loss, using bone turnover markers, BMD, and ex vivo bone resorption genes as surrogates (Xu et al. 2009, Wu et al. 2010, Cheung et al. 2011, Wang et al. 2015).

Studies investigating the patterns of bone loss in amenorrheic women have allowed a further delineation of the role of FSH on bone turnover independent of estrogen. Although women with either hypogonadotropic amenorrhea or hypergonadotropic amenorrhea were noted to have lower lumbar spine BMD compared with eumenorrheic controls, the hypergonadotropic group (FSH >40 IU/L) had significantly lower BMD compared with the hypogonadotropic amenorrheics (Devleta et al. 2004). In contrast, in a conflicting study FSH was found not to be an independent variable affecting such BMD differences in adolescent girls with hypergonadotropic or hypogonadotropic hypogonadism (Ozbek et al. 2016). These conflicting results could at least in part be explained by the difference in the mean age of females in the two studies (around 32 years vs 14 years), and may relate to the difference in the duration of excess FSH exposure between the two groups.

\section{Molecular studies on FSH and bone loss}

Starting with our discovery of the pro-resorptive action of $\mathrm{FSH}$, there is now a body of incontrovertible evidence for a direct effect of FSH on bone both in vitro and in vivo (Sun et al. 2006, Liu et al. 2010a,b, Wang et al. 2015). Of note, ovariectomy-induced bone loss in rats was accentuated by the injection of FSH (Liu et al. 2010a). Furthermore, the same group reported a protective effect on bones of the injection of an FSH inhibitor (Liu et al. 2010b). As noted earlier, we have blocked FSH action using an epitope-specific anti-FSH antibody to find a rescue of postovariectomy bone loss (Zhu et al. 2012a, b, Ji et al. 2018).

This action of FSH on bone appears to be mediated primarily by a distinct isoform of the FSHR, which is shorter than the full-length ovarian FSHR. The presence of the FSHR isoform on human CD14+ cells and osteoclasts has been confirmed using nested PCR primers specific to the shorter isoform (Robinson et al. 2010, Tourkova et al. 2015). There is also compelling data using near-infrared spectroscopy for the binding of fluorophore-labeled 
FSH (FSH-CH) to bone in vivo, in addition to ovarian and testicular tissues (Feng et al. 2017, Ji et al. 2018). Importantly, co-injection of a 100-fold molar excess of unlabeled FSH markedly attenuated these signals, demonstrating specificity (Feng et al. 2017, Ji et al. 2018).

Unlike their coupling to $\mathrm{G} \alpha_{\mathrm{s}}$ in ovarian follicular cells, FSHRs in bone are coupled to $\mathrm{G}_{\mathrm{i} 2 \alpha}$ resulting in reduced cyclic AMP levels. This action is also associated with the sensitization of MAP kinase, NFKB and AKT pathways to stimulate osteoclastogenesis (Sun et al. 2006). In addition, FSH increases osteoclast formation by enhancing the expression of RANK, along with an increased production of cytokines, including interleukin-1 $\beta$, tumor necrosis factor- $\alpha$ and interleukin-6 (Iqbal et al. 2006, Cannon et al. 2010, 2011).

Genetic studies investigating SNPs in the Fshr gene have further substantiated a link between FSH and bone loss. Specifically, an activating rs6166 SNP in the Fshr gene results in an increased risk of osteoporosis as seen by lower BMD and increased bone turnover markers in this group of women (Rendina et al. 2010). Moreover, digenic combinations resulting in skeletal protection were noted to have involvement of the BMP15 and Fshr genes (Mendoza et al. 2012).

\section{Development of highly specific blocking antibodies to FSH}

The biggest challenge with studying FSH action on bone in vivo is the confounding effects of estrogen, which change simultaneously with altered FSH signaling. While FSH can cause bone loss, it also promotes the secretion of ovarian estrogen - its primary biological function - and this results in protection of the otherwise pro-resorptive action of FSH.

Our anti-FSH antibody was generated with the goal of inhibiting FSH with minimal effects on estrogen. For this, we selected a 13-amino-acid-long peptide sequence on FSH $\beta$, which, we knew from computational modeling, would prevent the access of FSH into the FSHR pocket (Zhu et al. 2012a,b, Ji et al. 2018). Thus, we were able to titrate circulating levels of the antibody to inhibit FSH action on osteoclasts, while sparing ovarian function (Zhu et al. 2012a). This level of specificity would not have, at least in principle, been obtainable with an anti-FSHR antibody. When the polyclonal antibody was injected into ovariectomized mice, there was not only a reduction in osteoclastic bone resorption, but also an increase in new bone formation, prompting the exploration of osteoblastic
FSHRs (Zhu et al. 2012a). Notably, we discovered that FSHRs were present on osteoblast precursors, rather than on mature bone-forming osteoblasts. We have now raised and tested the effect of monoclonal anti-FSH antibodies against the mouse and corresponding human sequences, which differ by two amino acids (Ji et al. 2018). Both antibodies, Mf4 and Hf2, effectively prevent bone loss post ovariectomy, with $\mathrm{IC}_{50} \mathrm{~s}$ of 5.4 and $6.1 \mathrm{nM}$ for inhibition of osteoclastogenesis, respectively (Ji et al. 2018).

\section{FSH effects on body fat and thermogenesis}

Weight gain and changes in body composition are typically seen in women around the menopausal transition. Overall weight gain is prominent in perimenopausal and early postmenopausal women alike and has largely been attributed to aging independent of menstrual status (Sternfeld et al. 1999, Demerath et al. 2011, Trikudanathan et al. 2013, Zsakai et al. 2015). However, changes in body composition, specifically those accruing from visceral adiposity, have been closely linked to the menopausal transition (Gambacciani et al. 1999, Toth et al. 2000, Sowers et al. 2007, Lovejoy et al. 2008, Franklin et al. 2009, Lee et al. 2009, Ho et al. 2010, Janssen et al. 2010). Notably, high FSH levels are associated with increases in waist circumference, waist-hip ratio and visceral fat volume (Gavaler \& Rosenblum 2003, Sowers et al. 2007, Seth et al. 2013). Additionally, there seems to be a reduction in lean mass associated with higher FSH levels (Gourlay et al. 2012, Jaff et al. 2015, Liu et al. 2017). In contrast, the 11-year SWAN follow-up and the Pan Asia Menopause study report lower FSH levels in women with higher BMI. This discrepancy may be due to feedback inhibition of FSH secretion by estrogen produced from aromatization in fat tissue (De Pergola et al. 2006, Ausmanas et al. 2007, Tepper et al. 2012). Interestingly, there is no association between FSH and BMI in males (Bieniek et al. 2016, Yamacake et al. 2016), despite evidence for the reduction of body fat by FSH inhibition in male mice (Liu et al. 2017) (see below). However, there is limited evidence for a role for FSH in the pathophysiology of metabolic syndrome (Stefanska et al. 2014).

Our overall results attest to a role for FSH in promoting adiposity (Liu et al. 2017). Similar to bone, the adipocyte FSHR, which at least in 3T3.L1 cells is a variant of the ovarian FSHR, couples to $\mathrm{G} \alpha_{i}$ - this results in reduced cAMP levels and a subsequent decrease in the activation of the mitochondrial protein, uncoupling protein-1 (UCP1) in de-differentiated brown adipocytes (or thermo cells). 
This pathway, which opposes $\beta_{3}$ adrenergic stimulation, has been shown in previous studies to be linked downstream to the activation of cyclic AMP response element-binding protein (CREB) and lipogenesis. Expectedly, in differentiated adipocytes derived from 3T3. L1 cells, FSH increases the expression of genes related to lipid metabolism, namely $L p l, \quad F a s$ and Pparg (Cui et al. 2012).

Our anti-FSH antibody, which blocks FSH action in the face of unperturbed estrogen levels, not only reduces adiposity in a variety of mouse models, but also induces the transition of white adipocytes to energy-producing beige adipocytes (Liu et al. 2017). These murine models include mature male and female mice fed pairwise or ad libitum on a high-fat diet or on normal chow, sham-operated and ovariectomized mice, 8-month-old mice, and $\mathrm{Fshr}^{+/-}$mice (Liu et al. 2017). The data have been replicated and reproduced at multiple laboratories using multiple modalities, namely quantitative nuclear magnetic resonance (qNMR), dualenergy X-ray absorptiometry (DXA), $\mu$-CT, and manual weighing of tissues (Liu et al. 2017, Rosen \& Zaidi 2017). Equally impressive declines were noted in subcutaneous, visceral, perigonadal, inguinal and bone marrow fat compartments (Liu et al. 2017). The antibody reduced body fat to a level similar to that in haploinsufficient Fshr+/- mice, indicating a dominant action of FSH signaling. Importantly, however, the antibody did not further reduce body fat in these mice, establishing in vivo specificity (Liu et al. 2017).

In addition to inducing leanness, the anti-FSH antibody also induced the production of thermogenic adipose tissue. We noted abundant beige cells in UCP1stained sections of white adipose tissue. Beiging was contemporaneously documented by implanting Thermo cells into athymic nude mice, as well as through the use of the transgenic ThermoMouse, in which a luciferase $(L u c 2)$ gene construct is inserted into the Ucp1 locus to report UCP1 activation. Upon blocking FSH, we found increased LUC2 radiance initially in the brown fat-rich interscapular area, which was followed at around 8 weeks by increased radiance in the inguinal fat, primarily containing white adipose tissue. Quantitative PCR also showed increased expression of brown fat genes in white adipose tissue, namely Ucp1, Cox7, Cidea and Cox8a. Finally, the induced beiging was confirmed by documenting an increase in mitochondrial density in the PhAM mouse, as well as through indirect calorimetry using metabolic cages, where increases in energy expenditure and oxygen consumption were noted (Liu et al. 2017).

\section{FSH effects on cholesterol metabolism}

There is an increased prevalence of dyslipidemia and cholesterol accumulation around the menopausal transition, which has traditionally been linked to estrogen deficiency (Rossouw et al. 2002). However, there has been recent evidence that FSH might play a role in increasing hepatic cholesterol production, independent of serum estrogen. A recent study of 278 pre- and perimenopausal women found that serum FSH, total cholesterol (TC) and LDL cholesterol (LDL-C) levels were higher in the perimenopausal group compared with pre-menopausal women, despite similar serum estrogen levels (Guo et al. 2019). Serum FSH levels displayed a positive correlation with TC and LDL-C after adjustment for estrogen. Similarly, another study of 588 postmenopausal women noted that subjects with higher serum FSH levels had higher levels of both TC and LDL-C (Serviente et al. 2019). In a cohort of 400 postmenopausal Chinese women with a similar relationship between serum FSH, TC and LDL-C, it was noted that significant improvement of lipid levels after hormone-replacement therapy was seen only in women who had $\geq 30 \%$ reduction in serum FSH levels (Song et al. 2016).

To further substantiate a role for FSH in cholesterol metabolism, Guo et al. used ovariectomized mice in which estrogen was clamped by exogenous administration. These mice, when injected with recombinant FSH, showed higher levels of serum TC and LDL-C, and elevated hepatic cholesterol biosynthesis (Guo et al. 2019). Furthermore, in contrast to our results where we did not find decrements in serum cholesterol after 8 weeks of anti-FSH antibody treatment (Liu et al. 2017), the authors provide compelling evidence that blocking FSH action either through an anti-FSH $\beta$ antibody or in Fshr-/- mice significantly reduced serum and hepatic cholesterol content, without significantly altering estrogen levels (Guo et al. 2019). The presence of the FSHR in the liver was also established in both human and mouse liver samples using RT-PCR, in situ hybridization and immunofluorescent labeling (Guo et al. 2019). Finally, FSH was shown to upregulate liver HMGCoA reductase, a rate-limiting enzyme for cholesterol biosynthesis; this effect appears to be regulated through the activation of the transcription factor sterol regulatory element-binding protein 2 (SREBP-2) (Pertusa et al. 2007, Guo et al. 2019). Another possible mechanism of elevated circulating LDL-C is the FSH-mediated reduction in hepatic LDL receptors which results in decreased endocytosis of LDL-C. This was shown both by reduced hepatic LDLR expression in ovariectomized mice, as well 
as FSH-mediated LDLR inhibition in HepG2 cells (Song et al. 2016). Given the small number of studies on the topic, there is room for further exploration of the role of FSH on lipid and cholesterol metabolism and the underlying mechanisms.

\section{Effects on cardiovascular risk}

Although several studies have reported an association between serum FSH levels and markers of cardiovascular risk, it remains a controversial subject with lack of consistent findings. The Assessment of the Transition of Hormonal Evaluation and Noninvasive Imaging of Atherosclerosis study used contrast-enhanced CT angiography and carotid ultrasound to find that subclinical atherosclerosis is prevalent in perimenopausal women, with the prevalence of any coronary plaque being as high as $35.5 \%$ (Munir et al. 2012). Of note was that the number of aortic plaques was associated directly with serum $\mathrm{FSH}$ levels, but was unrelated to serum estrogen (Munir et al. 2012).

Similarly, a study from Brazil noted a significant positive correlation between serum FSH and carotid intima-media thickness, a surrogate for atherosclerosis (Celestino Catão Da Silva et al. 2013). Furthermore, data from a SWAN cohort showed lower serum FSH levels to be associated with a lower carotid intima-media thickness compared to the mid and high FSH groups, although the latter had a superior cardiovascular disease risk profile (El Khoudary et al. 2016). To the contrary, the SPECT-China study, a large, multi-center study on 2658 postmenopausal women, showed a negative association between serum FSH levels and atherosclerotic cardiovascular risk (Wang et al. 2017).

\section{FSH and the biology of aging}

Aside from what is now emerging as a critical function for high plasma FSH in causing physiologic perturbations of menopause, there has also been recent speculation for its role in the aging process per se in both sexes (Bartke 2017). Even in men, serum FSH levels rise by 3\% per annum (Feldman et al. 2002). In murine models, enhancements in longevity are associated with reduced FSH levels (Bartke 2017). Namely, Ames and Laron dwarf mice, which are deficient in the pituitary transcription factor PROP1 and growth hormone receptor, respectively, display reduced serum $\mathrm{FSH}$, in addition to other pituitary hormones. These mice display increases in brown adipose tissue, similar to what we have reported using our anti-FSH antibody (Bartke et al. 2013, Bartke 2017, Liu et al. 2017). In addition, there is an impressive increase in lifespan and reduced biological aging in these mice. However, further studies are needed to decipher the precise mechanism(s) underscoring increased longevity. In addition to possible effects on lifespan per se, one might speculate that the relationship between FSH and obesity may confer a survival benefit when FSH is low, particularly as adiposity can independently affect metabolic and cardiovascular outcomes, thus decreasing longevity.

\section{Conclusion}

Extensively validated sets of data provide compelling evidence that FSH inhibition reduces body fat and serum cholesterol, induces beiging and thermogenesis, and increases bone mass. Most of these studies have been carried out in animal models, given the ability to study the effects of FSH, somewhat independent of estrogen. This prompts the question whether a single FSH-blocking agent can have the therapeutic novelty of simultaneously treating and/or preventing osteoporosis, obesity and dyslipidemia, diseases that affect millions of women and men worldwide. Highly targeted monoclonal anti-FSH antibodies are thus being developed currently as first-inclass agents for human use. Further studies in humans examining the effects of varying levels of FSH against the above-mentioned parameters would help delineate its exact role, and the potential use of these FSH-blocking antibodies in clinical practice.

\section{Declaration of interest}

$\mathrm{M} \mathrm{Z}$ is a named inventor on a patent related to FSH and bone, owned by Icahn School of Medicine at Mount Sinai. M Z will receive royalties and/or licensing fees per Mount Sinai policies, in case the patent is commercialized. M Z also consults for Merck, Roche, and a number of financial consulting platforms. The other authors have nothing to disclose.

\section{Funding}

$\mathrm{M} \mathrm{Z}$ is grateful to the National Institutes of Health for grant support, namely R01 AG40132, R01 AR67066, R01 DK113627, and U19 AG60917.

\section{References}

Adami S, Bianchi G, Brandi ML, Giannini S, Ortolani S, Dimunno O, Frediani B, Rossini M \& BONTURNO study group 2008 Determinants of bone turnover markers in healthy premenopausal women. Calcified Tissue International 82 341-347. (https://doi.org/10.1007/ s00223-008-9126-5)

Akhter MP, Lappe JM, Davies KM \& Recker RR 2007 Transmenopausal changes in the trabecular bone structure. Bone 41 111-116. (https:// doi.org/10.1016/j.bone.2007.03.019)
(C) 2019 Society for Endocrinology Published by Bioscientifica Ltd. Printed in Great Britain 
Ausmanas MK, Tan DA, Jaisamrarn U, Tian XW \& Holinka CF 2007 Estradiol, FSH and LH profiles in nine ethnic groups of postmenopausal Asian women: the Pan-Asia Menopause (PAM) study. Climacteric 10 427-437. (https://doi. org/10.1080/13697130701610780)

Bartke A 2017 Can FSH influence longevity? Aging Cell 16 916-917. (https://doi.org/10.1111/acel.12663)

Bartke A, Sun LY \& Longo V 2013 Somatotropic signaling: trade-offs between growth, reproductive development, and longevity. Physiological Reviews 93 571-598. (https://doi.org/10.1152/ physrev.00006.2012)

Bieniek JM, Kashanian JA, Deibert CM, Grober ED, Lo KC, Brannigan RE, Sandlow JI \& Jarvi KA 2016 Influence of increasing body mass index on semen and reproductive hormonal parameters in a multi-institutional cohort of subfertile men. Fertility and Sterility 106 1070-1075. (https://doi.org/10.1016/j.fertnstert.2016.06.041)

Cannon JG, Cortez-Cooper M, Meaders E, Stallings J, Haddow S, Kraj B, Sloan G \& Mulloy A 2010 Follicle-stimulating hormone, interleukin-1, and bone density in adult women. American Journal of Physiology: Regulatory, Integrative and Comparative Physiology 298 R790-R798. (https://doi.org/10.1152/ajpregu.00728.2009)

Cannon JG, Kraj B \& Sloan G 2011 Follicle-stimulating hormone promotes RANK expression on human monocytes. Cytokine 53141 144. (https://doi.org/10.1016/j.cyto.2010.11.011)

Celestino Catão Da Silva D, Nogueira De Almeida Vasconcelos A, Cleto Maria Cerqueira J, De Oliveira Cipriano Torres D, Oliveira Dos Santos AC, De Lima Ferreira Fernandes Costa H \& Bregieiro Fernandes Costa LO 2013 Endogenous sex hormones are not associated with subclinical atherosclerosis in menopausal women. Minerva Ginecologica 65 297-302.

Chapurlat RD, Garnero P, Sornay-Rendu E, Arlot ME, Claustrat B \& Delmas PD 2000 Longitudinal study of bone loss in pre- and perimenopausal women: evidence for bone loss in perimenopausal women. Osteoporosis International 11 493-498. (https://doi. org/10.1007/s001980070091)

Cheung E, Tsang S, Bow C, Soong C, Yeung S, Loong C, Cheung CL, Kan A, Lo S, Tam S, et al. 2011 Bone loss during menopausal transition among southern Chinese women. Maturitas 69 50-56. (https://doi.org/10.1016/j.maturitas.2011.01.010)

Crandall CJ, Tseng CH, Karlamangla AS, Finkelstein JS, Randolph JF, Thurston RC, Huang MH, Zheng H \& Greendale GA 2013 Serum sex steroid levels and longitudinal changes in bone density in relation to the final menstrual period. Journal of Clinical Endocrinology and Metabolism 98 E654-E663. (https://doi.org/10.1210/jc.2012-3651)

Cui H, Zhao G, Liu R, Zheng M, Chen J \& Wen J 2012 FSH stimulates lipid biosynthesis in chicken adipose tissue by upregulating the expression of its receptor FSHR. Journal of Lipid Research 53 909-917. (https://doi.org/10.1194/jlr.M025403)

De Pergola G, Maldera S, Tartagni M, Pannacciulli N, Loverro G \& Giorgino R 2006 Inhibitory effect of obesity on gonadotropin, estradiol, and inhibin B levels in fertile women. Obesity 141954 1960. (https://doi.org/10.1038/oby.2006.228)

Demerath EW, Rogers NL, Reed D, Lee M, Choh AC, Siervogel RM, Chumlea WC, Towne B \& Czerwinski SA 2011 Significant associations of age, menopausal status and lifestyle factors with visceral adiposity in African-American and European-American women. Annals of Human Biology 38 247-256. (https://doi.org/10.310 9/03014460.2010.524893)

Devleta B, Adem B \& Senada S 2004 Hypergonadotropic amenorrhea and bone density: new approach to an old problem. Journal of Bone and Mineral Metabolism 22 360-364. (https://doi.org/10.1007/s00774004-0495-1)

Ebeling PR, Atley LM, Guthrie JR, Burger HG, Dennerstein L, Hopper JL \& Wark JD 1996 Bone turnover markers and bone density across the menopausal transition. Journal of Clinical Endocrinology and
Metabolism 81 3366-3371. (https://doi.org/10.1210/ jcem.81.9.8784098)

El Khoudary SR, Santoro N, Chen HY, Tepper PG, Brooks MM, Thurston RC, Janssen I, Harlow SD, Barinas-Mitchell E, Selzer F, et al. 2016 Trajectories of estradiol and follicle-stimulating hormone over the menopause transition and early markers of atherosclerosis after menopause. European Journal of Preventive Cardiology 23 694-703. (https://doi.org/10.1177/2047487315607044)

Feldman HA, Longcope C, Derby CA, Johannes CB, Araujo AB, Coviello AD, Bremner WJ \& Mckinlay JB 2002 Age trends in the level of serum testosterone and other hormones in middle-aged men: longitudinal results from the Massachusetts male aging study. Journal of Clinical Endocrinology and Metabolism 87 589-598. (https:// doi.org/10.1210/jcem.87.2.8201)

Feng Y, Zhu S, Antaris AL, Chen H, Xiao Y, Lu X, Jiang L, Diao S, Yu K, Wang Y, et al. 2017 Live imaging of follicle stimulating hormone receptors in gonads and bones using near infrared II fluorophore. Chemical Science 8 3703-3711. (https://doi.org/10.1039/c6sc04897h)

Franklin RM, Ploutz-Snyder L \& Kanaley JA 2009 Longitudinal changes in abdominal fat distribution with menopause. Metabolism: Clinical and Experimental 58 311-315. (https://doi.org/10.1016/j. metabol.2008.09.030)

Gallagher CM, Moonga BS \& Kovach JS 2010 Cadmium, folliclestimulating hormone, and effects on bone in women age 42-60 years, NHANES III. Environmental Research 110 105-111. (https://doi. org/10.1016/j.envres.2009.09.012)

Gambacciani M, Ciaponi M, Cappagli B, Benussi C, De Simone L \& Genazzani AR 1999 Climacteric modifications in body weight and fat tissue distribution. Climacteric 2 37-44. (https://doi. org/10.3109/13697139909025561)

Garcia-Martin A, Reyes-Garcia R, Garcia-Castro JM, Rozas-Moreno P, Escobar-Jimenez F \& Munoz-Torres M 2012 Role of serum FSH measurement on bone resorption in postmenopausal women. Endocrine 41 302-308. (https://doi.org/10.1007/s12020-011-9541-7)

Gavaler JS \& Rosenblum E 2003 Predictors of postmenopausal body mass index and waist hip ratio in the Oklahoma postmenopausal health disparities study. Journal of the American College of Nutrition 22 269-276. (https://doi.org/10.1080/07315724.2003.10719303)

Gourlay ML, Specker BL, Li C, Hammett-Stabler CA, Renner JB \& Rubin JE 2012 Follicle-stimulating hormone is independently associated with lean mass but not BMD in younger postmenopausal women. Bone 50 311-316. (https://doi.org/10.1016/j. bone.2011.11.001)

Guo Y, Zhao M, Bo T, Ma S, Yuan Z, Chen W, He Z, Hou X, Liu J, Zhang Z, et al. 2019 Blocking FSH inhibits hepatic cholesterol biosynthesis and reduces serum cholesterol. Cell Research 29151 166. (https://doi.org/10.1038/s41422-018-0123-6)

Harlow SD, Gass M, Hall JE, Lobo R, Maki P, Rebar RW, Sherman S, Sluss PM, de Villiers TJ \& STRAW + 10 Collaborative Group 2012 Executive summary of the Stages of Reproductive Aging Workshop+10: addressing the unfinished agenda of staging reproductive aging. Journal of Clinical Endocrinology and Metabolism 97 1159-1168. (https://doi.org/10.1210/jc.2011-3362)

Ho SC, Wu S, Chan SG \& Sham A 2010 Menopausal transition and changes of body composition: a prospective study in Chinese perimenopausal women. International Journal of Obesity 34 12651274. (https://doi.org/10.1038/ijo.2010.33)

Iqbal J, Sun L, Kumar TR, Blair HC \& Zaidi M 2006 Follicle-stimulating hormone stimulates TNF production from immune cells to enhance osteoblast and osteoclast formation. PNAS 103 14925-14930. (https://doi.org/10.1073/pnas.0606805103)

Ito M, Nakamura T, Tsurusaki K, Uetani M \& Hayashi K 1999 Effects of menopause on age-dependent bone loss in the axial and appendicular skeletons in healthy Japanese women. Osteoporosis International 10 377-383. (https://doi.org/10.1007/s001980050243) 
Jaff NG, Norris SA, Snyman T, Toman M \& Crowther NJ 2015 Body composition in the Study of Women Entering and in Endocrine Transition (SWEET): a perspective of African women who have a high prevalence of obesity and HIV infection. Metabolism: Clinical and Experimental 64 1031-1041. (https://doi.org/10.1016/j. metabol.2015.05.009)

Janssen I, Powell LH, Kazlauskaite R \& Dugan SA 2010 Testosterone and visceral fat in midlife women: the Study of Women's Health Across the Nation (SWAN) fat patterning study. Obesity 18 604-610. (https://doi.org/10.1038/oby.2009.251)

Ji Y, Liu P, Yuen T, Haider S, He J, Romero R, Chen H, Bloch M, Kim SM, Lizneva D, et al. 2018 Epitope-specific monoclonal antibodies to FSHbeta increase bone mass. PNAS 115 2192-2197. (https://doi. org/10.1073/pnas.1718144115)

Lee CG, Carr MC, Murdoch SJ, Mitchell E, Woods NF, Wener MH, Chandler WL, Boyko EJ \& Brunzell JD 2009 Adipokines, inflammation, and visceral adiposity across the menopausal transition: a prospective study. Journal of Clinical Endocrinology and Metabolism 94 1104-1110. (https://doi.org/10.1210/jc.2008-0701)

Liu S, Cheng Y, Fan M, Chen D \& Bian Z 2010a FSH aggravates periodontitis-related bone loss in ovariectomized rats. Journal of Dental Research 89 366-371. (https://doi. org/10.1177/0022034509358822)

Liu S, Cheng Y, Xu W \& Bian Z $2010 b$ Protective effects of folliclestimulating hormone inhibitor on alveolar bone loss resulting from experimental periapical lesions in ovariectomized rats. Journal of Endodontics 36 658-663. (https://doi.org/10.1016/j.joen.2010.01.011)

Liu XM, Chan HC, Ding GL, Cai J, Song Y, Wang TT, Zhang D, Chen H, Yu MK, Wu YT, et al. 2015 FSH regulates fat accumulation and redistribution in aging through the Galphai/Ca(2+)/CREB pathway. Aging Cell 14 409-420. (https://doi.org/10.1111/acel.12331)

Liu P, Ji Y, Yuen T, Rendina-Ruedy E, DeMambro VE, Dhawan S, AbuAmer W, Izadmehr S, Zhou B, Shin AC, et al. 2017 Blocking FSH induces thermogenic adipose tissue and reduces body fat. Nature $\mathbf{5 4 6}$ 107-112. (https://doi.org/10.1038/nature22342)

Lovejoy JC, Champagne CM, De Jonge L, Xie H \& Smith SR 2008 Increased visceral fat and decreased energy expenditure during the menopausal transition. International Journal of Obesity 32 949-958. (https://doi.org/10.1038/ijo.2008.25)

Mendoza N, Quereda F, Presa J, Salamanca A, Sánchez-Borrego R, Vázquez F \& Astorquiza TM 2012 Estrogen-related genes and postmenopausal osteoporosis risk. Climacteric 15 587-593. (https:// doi.org/10.3109/13697137.2012.656160)

Munir JA, Wu H, Bauer K, Bindeman J, Byrd C, Feuerstein IM, Villines TC \& Taylor AJ 2012 The perimenopausal atherosclerosis transition: relationships between calcified and noncalcified coronary, aortic, and carotid atherosclerosis and risk factors and hormone levels. Menopause 19 10-15. (https://doi.org/10.1097/ gme.0b013e318221bc8d)

Ozbek MN, Demirbilek H, Baran RT \& Baran A 2016 Bone mineral density in adolescent girls with hypogonadotropic and hypergonadotropic hypogonadism. Journal of Clinical Research in Pediatric Endocrinology 8 163-169. (https://doi.org/10.4274/ jcrpe.2228)

Perrone G, Galoppi P, Capri O, Anelli G, Borrello M \& Zichella L 1995 Lumbar and femoral bone density in perimenopausal women with irregular cycles. International Journal of Fertility and Menopausal Studies 40 120-125.

Pertusa M, Morenilla-Palao C, Carteron C, Viana F \& Cabedo H 2007 Transcriptional control of cholesterol biosynthesis in Schwann cells by axonal neuregulin 1. Journal of Biological Chemistry 28228768 28778. (https://doi.org/10.1074/jbc.M701878200)

Randolph JF, Sowers M, Gold EB, Mohr BA, Luborsky J, Santoro N, McConnell DS, Finkelstein JS, Korenman SG, Matthews KA, et al. 2003 Reproductive hormones in the early menopausal transition: relationship to ethnicity, body size, and menopausal status. Journal of Clinical Endocrinology and Metabolism 88 1516-1522. (https://doi. org/10.1210/jc.2002-020777)

Recker R, Lappe J, Davies K \& Heaney R 2000 Characterization of perimenopausal bone loss: a prospective study. Journal of Bone and Mineral Research 15 1965-1973. (https://doi.org/10.1359/ jbmr.2000.15.10.1965)

Recker R, Lappe J, Davies KM \& Heaney R 2004 Bone remodeling increases substantially in the years after menopause and remains increased in older osteoporosis patients. Journal of Bone and Mineral Research 19 1628-1633. (https://doi.org/10.1359/JBMR.040710)

Rendina D, Gianfrancesco F, De Filippo G, Merlotti D, Esposito T, Mingione A, Nuti R, Strazzullo P, Mossetti G \& Gennari L 2010 FSHR gene polymorphisms influence bone mineral density and bone turnover in postmenopausal women. European Journal of Endocrinology 163 165-172. (https://doi.org/10.1530/EJE-10-0043)

Robinson LJ, Tourkova I, Wang Y, Sharrow AC, Landau MS, Yaroslavskiy BB, Sun L, Zaidi M \& Blair HC 2010 FSH-receptor isoforms and FSH-dependent gene transcription in human monocytes and osteoclasts. Biochemical and Biophysical Research Communications 394 12-17. (https://doi.org/10.1016/j. bbrc.2010.02.112)

Rosen CJ \& Zaidi M 2017 Contemporaneous reproduction of preclinical science: a case study of FSH and fat. Annals of the New York Academy of Sciences 1404 17-19. (https://doi.org/10.1111/nyas.13457)

Rossouw JE, Anderson GL, Prentice RL, LaCroix AZ, Kooperberg C, Stefanick ML, Jackson RD, Beresford SA, Howard BV, Johnson KC, et al. 2002 Risks and benefits of estrogen plus progestin in healthy postmenopausal women: principal results From the Women's Health Initiative randomized controlled trial. JAMA 288 321-333. (https:// doi.org/10.1001/jama.288.3.321)

Seifert-Klauss V, Mueller JE, Luppa P, Probst R, Wilker J, Hoss C, Treumann T, Kastner C \& Ulm K 2002 Bone metabolism during the perimenopausal transition: a prospective study. Maturitas 41 23-33. (https://doi.org/10.1016/S0378-5122(01)00248-1)

Seifert-Klauss V, Link T, Heumann C, Luppa P, Haseitl M, Laakmann J, Rattenhuber J \& Kiechle M 2006 Influence of pattern of menopausal transition on the amount of trabecular bone loss. Results from a 6-year prospective longitudinal study. Maturitas 55 317-324. (https:// doi.org/10.1016/j.maturitas.2006.04.024)

Senapati S, Gracia CR, Freeman EW, Sammel MD, Lin H, Kim C, Schwab RJ \& Pien GW 2014 Hormone variations associated with quantitative fat measures in the menopausal transition. Climacteric 17 183-190. (https://doi.org/10.3109/13697137.2013.845876)

Serviente C, Tuomainen TP, Virtanen J, Witkowski S, Niskanen L \& Bertone-Johnson E 2019 Follicle-stimulating hormone is associated with lipids in postmenopausal women. Menopause 26 540-545. (https://doi.org/10.1097/GME.0000000000001273)

Seth B, Arora S \& Singh R 2013 Association of obesity with hormonal imbalance in infertility: a cross-sectional study in north Indian women. Indian Journal of Clinical Biochemistry 28 342-347. (https:// doi.org/10.1007/s12291-013-0301-8)

Song Y, Wang ES, Xing LL, Shi S, Qu F, Zhang D, Li JY, Shu J, Meng Y, Sheng JZ, et al. 2016 Follicle-stimulating hormone induces postmenopausal dyslipidemia through inhibiting hepatic cholesterol metabolism. Journal of Clinical Endocrinology and Metabolism 101 254-263. (https://doi.org/10.1210/jc.2015-2724)

Sowers MR, Finkelstein JS, Ettinger B, Bondarenko I, Neer RM, Cauley JA, Sherman S, Greendale GA \& Study of Women's Health Across the Nation 2003 The association of endogenous hormone concentrations and bone mineral density measures in pre- and perimenopausal women of four ethnic groups: SWAN. Osteoporosis International 14 44-52. (https://doi.org/10.1007/s00198-0021307-x)

Sowers MR, Jannausch M, Mcconnell D, Little R, Greendale GA, Finkelstein JS, Neer RM, Johnston J \& Ettinger B 2006 Hormone predictors of bone mineral density changes during the menopausal 
transition. Journal of Clinical Endocrinology and Metabolism 91 12611267. (https://doi.org/10.1210/jc.2005-1836)

Sowers M, Zheng H, Tomey K, Karvonen-Gutierrez C, Jannausch M, Li X, Yosef M \& Symons J 2007 Changes in body composition in women over six years at midlife: ovarian and chronological aging. Journal of Clinical Endocrinology and Metabolism 92 895-901. (https:// doi.org/10.1210/jc.2006-1393)

Stefanska A, Ponikowska I, Cwiklinska-Jurkowska M \& Sypniewska G 2014 Association of FSH with metabolic syndrome in postmenopausal women: a comparison with CRP, adiponectin and leptin. Biomarkers in Medicine 8 921-930. (https://doi.org/10.2217/ bmm.14.49)

Sternfeld B, Quesenberry CP \& Husson G 1999 Habitual physical activity and menopausal symptoms: a case-control study. Journal of Women's Health 8 115-123. (https://doi.org/10.1089/jwh.1999.8.115)

Sun L, Peng Y, Sharrow AC, Iqbal J, Zhang Z, Papachristou DJ, Zaidi S, Zhu LL, Yaroslavskiy BB, Zhou H, et al. 2006 FSH directly regulates bone mass. Cell 125 247-260. (https://doi.org/10.1016/j. cell.2006.01.051)

Sun L, Zhang Z, Zhu LL, Peng Y, Liu X, Li J, Agrawal M, Robinson LJ, Iqbal J, Blair HC, et al. 2010 Further evidence for direct proresorptive actions of FSH. Biochemical and Biophysical Research Communications 394 6-11. (https://doi.org/10.1016/j. bbrc.2010.02.113)

Tepper PG, Randolph JF, McConnell DS, Crawford SL, El Khoudary SR, Joffe H, Gold EB, Zheng H, Bromberger JT \& Sutton-Tyrrell K 2012 Trajectory clustering of estradiol and follicle-stimulating hormone during the menopausal transition among women in the Study of Women's Health across the Nation (SWAN). Journal of Clinical Endocrinology and Metabolism 97 2872-2880. (https://doi. org/10.1210/jc.2012-1422)

Thurston RC, Sowers MR, Sternfeld B, Gold EB, Bromberger J, Chang Y, Joffe H, Crandall CJ, Waetjen LE \& Matthews KA 2009 Gains in body fat and vasomotor symptom reporting over the menopausal transition: the study of women's health across the nation. American Journal of Epidemiology 170 766-774. (https://doi.org/10.1093/aje/ kwp203)

Toth MJ, Tchernof A, Sites CK \& Poehlman ET 2000 Menopause-related changes in body fat distribution. Annals of the New York Academy of Sciences 904 502-506. (https://doi.org/10.1111/j.1749-6632.2000. tb06506.x)

Tourkova IL, Witt MR, Li L, Larrouture Q, Liu L, Luo J, Robinson LJ \& Blair HC 2015 Follicle stimulating hormone receptor in mesenchymal stem cells integrates effects of glycoprotein reproductive hormones. Annals of the New York Academy of Sciences 1335 100-109. (https://doi.org/10.1111/nyas.12502)

Trikudanathan S, Pedley A, Massaro JM, Hoffmann U, Seely EW, Murabito JM \& Fox CS 2013 Association of female reproductive factors with body composition: the Framingham Heart Study. Journal of Clinical Endocrinology and Metabolism 98 236-244. (https://doi. org/10.1210/jc.2012-1785)

Wang J, Zhang W, Yu C, Zhang X, Zhang H, Guan Q, Zhao J \& Xu J 2015 Follicle-stimulating hormone increases the risk of postmenopausal osteoporosis by stimulating osteoclast differentiation. PLOS ONE 10 e0134986. (https://doi.org/10.1371/ journal.pone.0134986)

Wang N, Shao H, Chen Y, Xia F, Chi C, Li Q, Han B, Teng Y \& Lu Y 2017 Follicle-stimulating hormone, its association with cardiometabolic risk factors, and 10-year risk of cardiovascular disease in postmenopausal women. Journal of the American Heart Association 6 e005918. (https://doi.org/10.1161/JAHA.117.005918)

Wu XY, Wu XP, Xie H, Zhang H, Peng YQ, Yuan LQ, Su X, Luo XH \& Liao EY 2010 Age-related changes in biochemical markers of bone turnover and gonadotropin levels and their relationship among Chinese adult women. Osteoporosis International 21 275-285. (https:// doi.org/10.1007/s00198-009-0943-9)

Xu ZR, Wang AH, Wu XP, Zhang H, Sheng ZF, Wu XY, Xie H, Luo XH \& Liao EY 2009 Relationship of age-related concentrations of serum FSH and LH with bone mineral density, prevalence of osteoporosis in native Chinese women. Clinica Chimica Acta: International Journal of Clinical Chemistry 400 8-13. (https://doi.org/10.1016/j. cca.2008.09.027)

Yamacake KG, Cocuzza M, Torricelli FC, Tiseo BC, Frati R, Freire GC, Antunes AA \& Srougi M 2016. Impact of body mass index, age and varicocele on reproductive hormone profile from elderly men. International Brazilian Journal of Urology 42 365-372.

Zaidi M 2007 Skeletal remodeling in health and disease. Nature Medicine 13 791-801. (https://doi.org/10.1038/nm1593)

Zaidi M, New MI, Blair HC, Zallone A, Baliram R, Davies TF, Cardozo C, Iqbal J, Sun L, Rosen CJ, et al. 2018a Actions of pituitary hormones beyond traditional targets. Journal of Endocrinology 237 R83-R98. (https://doi.org/10.1530/JOE-17-0680)

Zaidi M, Yuen T, Sun L \& Rosen CJ $2018 b$ Regulation of skeletal homeostasis. Endocrine Reviews 39 701-718. (https://doi.org/10.1210/ er.2018-00050)

Zhu LL, Blair H, Cao J, Yuen T, Latif R, Guo L, Tourkova IL, Li J, Davies TF, Sun L, et al. 2012a Blocking antibody to the beta-subunit of FSH prevents bone loss by inhibiting bone resorption and stimulating bone synthesis. PNAS 109 14574-14579. (https://doi. org/10.1073/pnas.1212806109)

Zhu LL, Tourkova I, Yuen T, Robinson LJ, Bian Z, Zaidi M \& Blair HC $2012 b$ Blocking FSH action attenuates osteoclastogenesis. Biochemical and Biophysical Research Communications 422 54-58. (https://doi. org/10.1016/j.bbrc.2012.04.104)

Zsakai A, Mascie-Taylor N \& Bodzsar EB 2015 Relationship between some indicators of reproductive history, body fatness and the menopausal transition in Hungarian women. Journal of Physiological Anthropology 34 35. (https://doi.org/10.1186/s40101-015-0076-0) (c) 2019 Society for Endocrinology Published by Bioscientifica Ltd. Printed in Great Britain
Received in final form 18 August 2019

Accepted 27 August 2019

Accepted Preprint published online 27 August 2019 